\title{
Wspomaganie rozwoju funkcii wykonawczych dzieci w wieku przedszkolnym jako wczesne działanie profilaktyczne
}

\author{
Supporting the Development of the Executive \\ Functions of Pre-school Children as an Early \\ Preventive Action
}

\begin{abstract}
ABSTRAKT
Intensywny rozwój fizyczny, emocjonalno-społeczny, poznawczy i moralny dzieci w wieku przedszkolnym sprawia, że interwencja profilaktyczna wprowadzona w tak wczesnym wieku może przynieść korzyści i prowadzić do znaczqcych zmian w teraźniejszym i przyszłym funkcjonowaniu dziecka. Dynamiczny rozwój funkcji wykonawczych, który przypada na 4-5 rok życia dziecka, wspomagany w ramach działań profilakłycznych, może się przyczynić do wzmocnienia gotowości szkolnej, wyższych wyników w zakresie umiejętności ięzykowych, matematycznych oraz kompetencji społecznych. W artykule przedstawiono pojęcie funkcji wykonawczych i ich typy. Metoda badawczq zastosowanq do pogłębienia wiedzy na temat umiejętności wykonawczych i ich znaczenia dla rozwoju dzieci była analiza treści. Uwzględniono również argumenty za tworzeniem dzieciom warunków do rozwoju funkcji wykonawczych jako czynnika chroniqcego w kolejnych latach edukacji przed przyszłymi zachowaniami antyspołecznymi, uzależnieniami behawioralnymi oraz od substancji psychoaktywnych. W ostatniej części zaprezentowano przykłady działań wczesnej profilaktyki, które można włączyć do edukacji dziecka w wieku przedszkolnym.
\end{abstract}

StOWA KLUCZOWE funkcja wykonawcza dzieci, wczesne działanie profilaktyczne, dzieci w wieku przedszkolnym, funkcja wykonawcza jako czynnik chroniq̨cy

\section{KEYWORDS}

executive function of children, early preventive action, pre-school children, executive function as a protective factor

SPI Vol. 22, 2019/3

ISSN 2450-5358

e-ISSN 2450-5366

DOI: 10.12775/SPI.2019.3.005

Nadesłano: 31.07 .2019

Zaakceptowano: 3.11.2019

Artykuły i rozprawy 


\section{ABSTRACT}

The intensive physical, socio-emotional, cognitive and moral development of children at pre-school age means that preventive intervention introduced at such an early age can bring benefits and lead to significant changes in the child's present and future functioning. When supported as a part of preventive activities, the dynamic development of executive functions which falls around the age of $4-5$ in a child's life can contribute to the strengthening of school readiness, and higher results in the following areas: language skills, mathematics and social competences. In the article, the author has presented the concept of executive functions and their types. Also taken into account are arguments for creating conditions for children to develop executive functions as a factor protecting their educational development against future anti-social behavior, behavioral addictions and psychoactive substances. In the last part, the author presents examples of early prevention measures that can be included in the education of a pre-school child.

\section{Poięcie funkcii wykonawczych}

Funkcje wykonawcze (FW) (zarządzające/zarządcze) ${ }^{1}$ są wyższymi funkcjami poznawczymi, których sprawność nabywana jest $\mathrm{w}$ różnym czasie. To dzięki nim człowiek kieruje swoimi działaniami od najprostszych związanych z samoobsługą, po te bardziej skomplikowane, wymagające złożonych procedur, np. planowania i wykonywania wieloetapowych obowiązków domowych lub projektów na różnych etapach edukacji i w życiu zawodowym. Pomimo wielu badań prowadzonych w tym zakresie, naukowcy nie są jednoznacznie przekonani jakie dokładnie umiejętności wchodzą w skład FW².

1 Edward Nęcka, Jarosław Orzechowski i Błażej Szymura (2013) tłumaczą angielski termin executive function jako funkcje zarządcze, natomiast Maria Kielar-Turska - funkcje zarządzające (Kielar-Turska, Białecka-Pikul, Skórska 2006). W artykule korzystam z tłumaczenia Adama Putki (2008) tego terminu jako funkcje wykonawcze i w dalszej jego części będę korzystać ze skrótu FW.

2 Sonia Packwood, Helen Hodgetts i Sébastien Tremblay (2011) po przeanalizowaniu 60 wyników badań zidentyfikowali 68 komponentów FW. Usunęli te komponenty, które nachodziły na siebie znaczeniowo i psychometrycznie (te same zadania diagnozowały inne funkcje) i po zastosowaniu analizy 
Najczęściej podawane komponenty to: hamowanie reakcji (inbibition), pamięć robocza (working memory), przerzutność uwagi (set shifting), planowanie (planning), płynność (fluency) powiązana w badaniach z modulowaną reakcją. Akira Miyake i Naomi P. Friedman (2012: 8-10) wyróżnili trzy typy funkcji wykonawczych:

a) Przerzutność pomiędzy zadaniami, procesami, czynnościami, rozumianą jako zdolność uwagi do przełączania się między dwoma zadaniami, „obsługiwanymi przez niezależne procesy przetwarzania informacji” (Jersild 1927 za: Nęcka i in. 2013: 184). Przerzucanie uwagi wymaga zahamowania jednego procesu poznawczego i uruchomienia procesu alternatywnego, co wiąże $z$ kosztami poznawczymi, np. zwiększoną ilością czasu potrzebnego do wykonania zadania bądź większym ryzykiem błędu.

b) Hamowanie rozumiane jako blokowanie jakichkolwiek pobudek, zarówno zewnętrznych (bodźce nieważne, dystraktory), jak i wewnętrznych (bodźce „symboliczne”, impulsy, czynniki afektywne lub motywacyjne), które mogłyby wyzwolić reakcje konkurencyjne względem aktualnie wykonywanych czynności i przez to wywołać zjawisko interferencji zasobowej (Nigg 2000, za: Nęcka i in. 2013: 251-251).

c) Odświeżanie informacji w zakresie pamięci roboczej.

$\mathrm{Z}$ perspektywy zdrowia psychicznego rozwinięte funkcje wykonawcze mogą odgrywać kluczową rolę w życiu dziecka, stanowiąc podstawę zarówno gotowości do nauki, sukcesów szkolnych, przejawiających się nie tylko osiągnięciami językowymi i matematycznymi, ale również wynikającymi z wysokich kompetencji społecznych (Blair, Zelazo, Greenberg 2005: 561). Założyłam, że rozpoczęcie działań profilaktycznych znacznie wyprzedzających możliwość pojawienia się problemów w rozwoju psychospołecznym i zachowań ryzykownych może wzmocnić realizację zadań rozwojowych (Brzezińska, Appelt, Ziółkowska 2016: 162-164) oraz podnieść na wyższy poziom te umiejętności, które aktualnie i w przyszłości mogą pełnić

skupień (miar odległości i drzewa hierarchicznego) wyłonili najpierw 12 obszarów silnie powiązanych z FW, potem określili 18 umiejętności. Zarazem podkreślili przydatność wykorzystanych analiz i zasygnalizowali konieczność prowadzenia dalszych badań w tym zakresie. 
znaczącą funkcję nie tylko radzeniu sobie $z$ konstruktywnymi wymaganiami dorosłych, ale i w budowaniu relacji z rówieśnikami.

W 2-3 roku życia dziecka rodzi poczucie jego autonomii. Istotne jest wtedy, aby dziecko rozwijało się stopniowo poprzez przejmowanie kontroli nad sobą i swoim zachowaniem. Ważnym rozwojowo doświadczeniem, zachowaniem, stanem wewnętrznym dla dziecka są zarówno przejawy autonomii, jak i podporządkowania, które wskazują na nabywanie umiejętności koordynowania własnej woli z wymaganiami społecznymi. W tej fazie rozwojowej pojawia się napięcie autonomia versus wstyd i zwątpienie (Erikson 1997: 261-265). Według Erika H. Eriksona (1997: 262) regulacja zewnętrzna powinna stopniowo ukierunkowywać doświadczenie autonomii wolnego wyboru i „przynosić zdecydowaną pociechę, rozwiewać obawy”, gdy jednak pojawia się w zbyt inwazyjnej formie, może prowadzić do przedwczesnego, zbyt sztywnego rozwoju sumienia, nadmiernej manipulacji samym sobą prowadzącej do zahamowania aktywności bądź nadmiernej kontroli. Wstyd pojawia się wtedy, gdy dziecko zaczyna zdawać sobie sprawę z tego, że jest wystawione na spojrzenia innych i ma ochotę się ukryć. W tym okresie dziecko uczy się przeżywać frustrację jako naturalny stan, który towarzyszy różnym zdarzeniom. Istotne dla prawidłowego rozwoju dziecka jest to, żeby miało możliwość podejmowania decyzji we wszystkich tych sprawach, w których może je podjąć. Dzięki takim warunkom do rozwoju u dziecka może się rozwijać poczucie sprawstwa.

W dalszym rozwoju dziecko jako 4-6-latek staje przed wyzwaniem dotyczącym napięcia między inicjatywą a poczuciem winy. Pojawia się przyjemność w osiąganiu celu, stąd wypływa energia do inicjowania aktywności i doświadczanie przyjemności realizowania własnych pomysłów. Przy uzyskiwanej coraz większej sprawności i energii zdarzają się konflikty związane z chęcią zawłaszczenia przez dziecko sfery wyobraźni, przedmiotów, ludzi i konieczność szukania sposobów radzenia sobie z tym wyzwaniem (Smykowski 2005: 171-177), by poczucie winy w uzasadnionych sytuacjach przekroczenia norm społecznych nie przytłoczyło uzasadnionej rozwojem gotowości do działania.

Wszelkie zabiegi wychowawcze i edukacyjne przynoszą wówczas najlepsze efekty, gdy są wprowadzone w momencie, kiedy dana umiejętność jeszcze nie dojrzała (Wygotski 1971: 521). Wprawdzie FW 
rozwijają się do 18-25 roku życia, jednakże najintensywniejszy ich rozwój przypada na 4-5 rok życia (Carlson 2005; Garon, Bryson, Smith 2008, za: Hammond i in. 2012: 271). Dodatkowo ważne jest, że te umiejętności są podatne na oddziaływania ze strony środowiska fizycznego i społeczno-kulturowego (Brzezińska, Nowotnik 2012: 3), a wysoki poziom FW jest istotny dla osiągnięć edukacyjnych i tworzenia satysfakcjonujących relacji z rówieśnikami aż do okresu dojrzewania (Holmes, Kim-Spoon, Deater-Deckard, Tech 2016).

\section{Funkcje wykonawcze jako czynnik chroniący}

W określeniu dróg prowadzących do ryzyka używania substancji psychoaktywnych i powstawania innych zachowań ryzykownych podaje się zarówno splot czynników ryzyka, jak i czynników chroniących. Jednym z czynników ryzyka jest niewłaściwa realizacja ról rodzicielskich przejawiająca się np. brakiem czułości, nadmiernym krytycyzmem, wrogością, niedostateczną lub niekonsekwentną dyscypliną, niedostatecznym angażowaniem się w opiekę nad dzieckiem (Deptuła 2005: 159-172). Do rodzinnych czynników ryzyka zalicza się:

- brak pozytywnej więzi pomiędzy dzieckiem i jego opiekunem, co może wynikać z braku umiejętności wychowawczych lub niespójności w ich stosowaniu;

- nieumiejętność okazywania dziecku emocji lub niedopuszczanie przez rodzica do ekspresji przez dziecko emocji;

- niekonsekwencję postawy rodzicielskiej w przestrzeganiu norm obowiązujących w relacji dziecko-rodzic, charakteryzującej się nadmierną kontrolą bądź opiekuńczością;

- nieudzielanie dziecku wsparcia w pokonywaniu trudności, z którymi się boryka (Cierpiałowska, Ziarko 2010: 395-386).

Taka relacja $z$ rodzicami $w$ wieku przedszkolnym skutkuje rozwojem zachowań agresywnych, odmową podporządkowania się dorosłym w okresie przedszkolnym (Deptuła 2005: 159), jak również deficytami w rozwoju FW oraz gotowości szkolnej.

Dalsze konsekwencje nieadekwatnego pełnienia ról rodzicielskich, pojawiające się w młodszym wieku szkolnym, związane są z odrzuceniem dziecka w klasie szkolnej, jak również słabymi postępami w nauce. Konsekwencją tego stanu rzeczy jest zagrożenie pojawiające się 
w okresie dorastania związane z poszukiwaniem grup rówieśniczych, które nie przestrzegają konstruktywnych, społecznie akceptowanych norm i preferują używanie substancji psychoaktywnych.

Schemat 1. Indywidualna ścieżka ryzyka zapoczątkowana zaburzeniami realizacji ról rodzicielskich

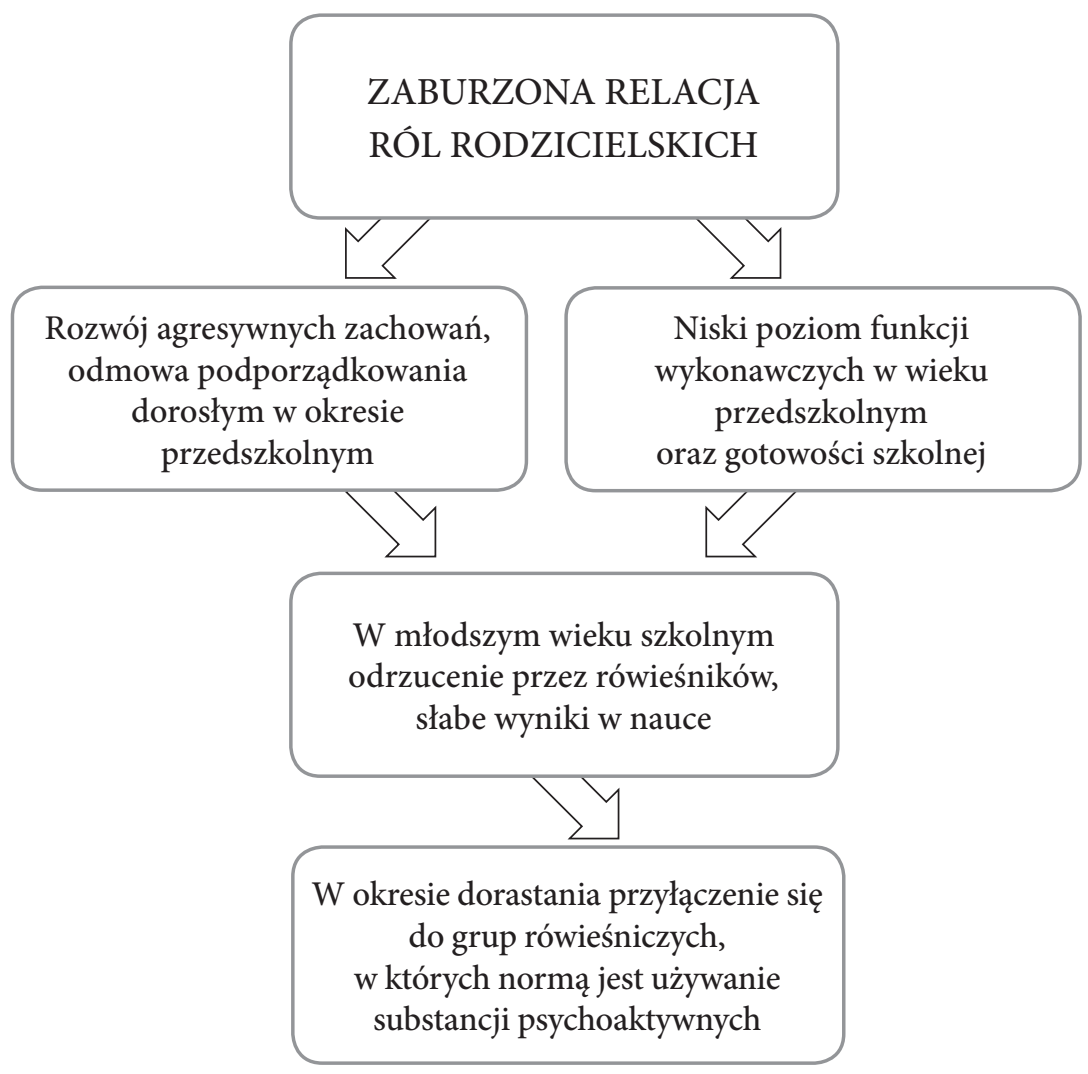

Źródło: Opracowanie własne na podstawie: Deptuła (2005); Maccoby, Martin (1983); McGrath, Noble (2010) (za: Whitebread, 2018).

Responsywność rodziców oraz umiejętność tworzenia „rodzicielskiego rusztowania" w toku rozwoju kształtują zdolność dziecka do samoregulacji poprzez nadawanie znaczenia i strukturowanie zarówno aktywności, jak i doznań dziecka (Brzezińska, Nowotnik 2012: 6; Dawson, Guare 2012: 110). Naukowcy (Maccoby, Martin 1983; McGrath, Noble 2010, za: Whitebread 2018: 328) podkreślają, że rodzice prezentujący autorytatywny styl wychowania tworzą 
najbardziej sprzyjające warunki do rozwoju samoregulacji, umiejętności wykonawczych, kompetencji społecznych. Ich styl przejawia się budowaniem $z$ dzieckiem ciepłych emocjonalnie relacji, w których nie brakuje serdeczności i zarazem wprowadzania wyjaśnionych, wynegocjowanych jasnych reguł postępowania. Rodzice autorytatywni respektują potrzeby dziecka (np. autonomii, wsparcia), egzekwując wymagania wyjaśniają swoje postępowanie i rzadko uciekają się do manifestowania władzy. Metaanalizy prowadzonych od 2000 do 2012 roku 42 badań nad znaczeniem rodzicielskich zachowań dla rozwoju FW u dzieci w wieku od 0 do 8 lat wskazują na związek pomiędzy tymi zmiennymi (Valcan, Davis, Pino-Psternak 2017). Zachowania sklasyfikowane jako pozytywne: okazywanie ciepła, wrażliwe reagowanie na sygnały płynące od dziecka, wspieranie autonomii, budowanie rusztowania, stymulacja poznawcza były związane z wyższymi FW dzieci. Przy czym im młodsze były dzieci, tym silniejszy był związek między zmiennymi, gdzie pozytywne zachowanie rodziców było istotnie statystycznie związane z wyższymi FW, natomiast nadmierna kontrola, bycie natarczywym albo obojętnym skutkowało niższymi osiągnięciami dzieci w tym zakresie. Wczesne dzieciństwo może być zatem krytycznym okresem, w którym zachowanie rodzicielskie może mieć szczególne znaczenie dla rozwoju FW dziecka.

Zgodnie $z$ wiedzą na temat trajektorii prowadzących do sięgania po środki psychoaktywne, jednym z czynników ryzyka są zaburzenia zdolności poznawczych, np.: obniżona zdolność koncentracji uwagi, percepcji wzrokowej, koordynacji wzrokowo-słuchowo-ruchowej. Nieprawidłowości w funkcjonowaniu uwagi przejawiają się takimi trudnościami jak: liczne pomyłki, gubienie się w instrukcjach, trudności z rozpoczynaniem i kończeniem zadań, trudności w funkcjonowaniu pamięci roboczej i przenoszeniu informacji do pamięci długotrwałej. Takim przejawom może towarzyszyć podwyższony poziom impulsywności, co wiąże się z brakiem systematyczności w przyswajaniu i integracji napływających informacji oraz niedostrzeganiem zależności pomiędzy pojęciami a obiektami (Nowotnik 2012: 90). Tego typu trudności niosą ze sobą zwiększone ryzyko pojawienia się problemów w nauce, czemu dodatkowo towarzyszy obniżona zdolność do radzenia sobie $z$ nimi. Kolejne elementy tej trajektorii to znaczne ryzyko odrzucenia przez rówieśników, skutkujące przyłączeniem się 
do grup rówieśniczych, w których normą jest używanie substancji psychoaktywnych (Deptuła 2005: 3). Obniżona zdolność radzenia sobie $\mathrm{z}$ problemami $\mathrm{w}$ nauce powiązana jest $\mathrm{z}$ niskim poziomem samoregulacji poznawczej, behawioralnej i emocjonalnej, intensywnie rozwijającej się w 2-3 roku życia. Umiejętności regulowania stanów poznawczych, emocjonalnych oraz zachowania ujawniają się dzięki funkcjom wykonawczym i są silniejszym niż iloraz inteligencji predyktorem gotowości szkolnej, umiejętności szkolnych, jakości życia i innych aspektów rozwoju dziecka (Veenman, Spaans 2005, za: Whitebread 2018: 327) oraz osiągnięć szkolnych (McClelland i in. 2013, za: Whitebread 2018: 327). Uzasadnieniem dla wspomagania rozwoju funkcji wykonawczych dzieci w wieku przedszkolnym - czynnika chroniącego - są wyniki badań wskazujące na predykcyjną rolę pamięci roboczej (wchodzącej w skład FW). Na podstawie wyników badań prowadzonych w grupie 4-letnich szkockich i amerykańskich dzieci, stwierdzono, że im wyższe wyniki w zakresie pamięci roboczej $\mathrm{w}$ wieku przedszkolnym, tym wyższy poziom umiejętności matematycznych i ogólny sukces szkolny w trzecim roku edukacji wczesnoszkolnej (Bull, Espy, Wiebe 2008: 205).

Wprawdzie powyżej przedstawiona trajektoria rozpoczyna się $\mathrm{w}$ wieku szkolnym, jednakże biorąc pod uwagę znaczenie gotowości szkolnej w osiąganiu sukcesów szkolnych można ją rozszerzyć o niski poziom FW prowadzący do niskiego poziomu gotowości do kolejnego etapu edukacji. 
Schemat 2. Indywidualna ścieżka ryzyka zapoczq̨tkowana niskim poziomem funkcji wykonawczych i gotowości szkolnej

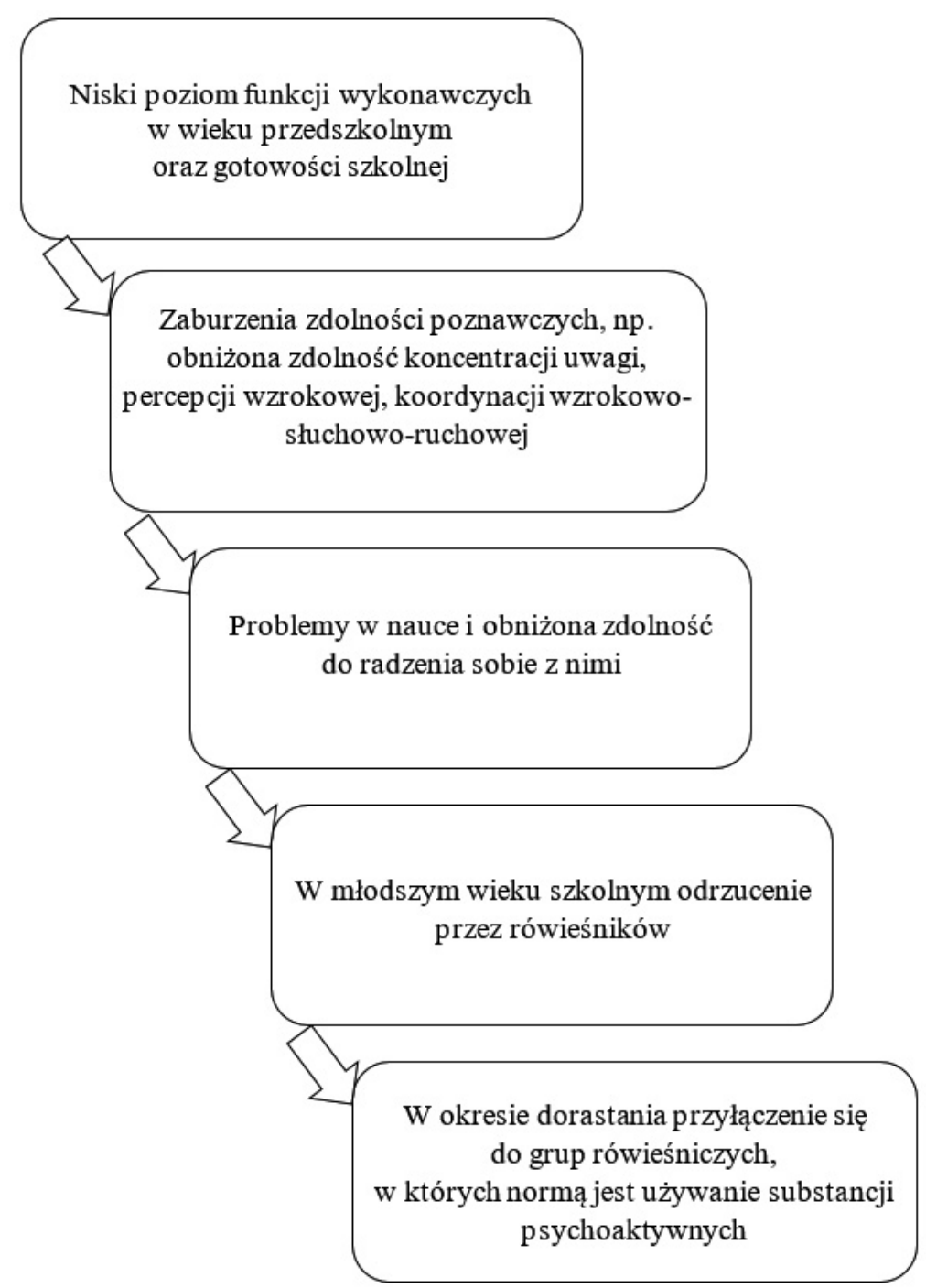

Źródło: Opracowanie własne na podstawie: Deptuła (2005); Bull, Espy, Wiebe (2008).

Wiedza na temat funkcji wykonawczych oraz sposobów ich wspomagania może posłużyć do planowania wczesnych działań profilaktycznych osłabiających siłę wpływu czynnika ryzyka związanego 
z upośledzeniem zdolności kontrolowania swojego zachowania, problemami z koncentracją uwagi, deficytami poznawczymi prowadzących do niskich osiągnięć szkolnych, a praca z rodzicami mogłaby się przyczynić do zmniejszenia oddziaływania czynnika zaburzonej realizacji ról rodzicielskiej.

\section{Wspomaganie rozwoju funkcji wykonawczych dzieci w wieku przedszkolnym}

Wczesne działania profilaktyczne to przede wszystkim przygotowanie rodziców i nauczycieli do wspomagania rozwoju FW dzieci. Ważnym działaniem byłoby stwarzanie głównym opiekunom dziecka warunków do:

- zdobywania wiedzy na temat rozwoju dziecka, warunków koniecznych do prawidłowego rozwoju oraz znaczenia funkcji wykonawczych na kolejnych etapach życia;

- rozpoznawania stanu posiadanych zarówno przez głównych opiekunów, jak i dziecko umiejętności wchodzących w skład FW oraz deficytów w tym zakresie;

- rozwijania umiejętności wychowawczych poprzez organizację przestrzeni, budowania „rusztowania”, bezpośrednią komunikację oraz wykorzystywanie gier i zabaw;

- refleksji nad dotychczasowymi praktykami wychowawczymi i poszukiwania takich, które wspomagają rozwój FW.

W dalszej części opracowania skoncentrowałam się na przedstawieniu przykładów dobrych praktyk w zakresie organizacji przestrzeni, budowania rusztowania oraz wykorzystania gier i zabaw we wzmacnianiu umiejętności wchodzących w skład FW.

\section{Organizacja przestrzeni sprzyjajacej rozwojowi funkcji wykonawczych}

W nauce nowych umiejętności warto uwzględniać czynniki poprzedzające pojawienie się oczekiwanego zachowania, tworząc dzieciom sprzyjające warunki przestrzenne i materialne do rozwoju pożądanych umiejętności. Środowisko przestrzenne i materialne staje się dla dziecka okazją do poznawania i manipulowania 
przedmiotami, jak i projektowania nowego ich zastosowania. Alicja Potorska (Deptuła, Potorska, Borsich 2018: 79-85), korzystając z koncepcji społecznej psychologii środowiskowej Augustyna Bańki (2002), zaproponowała własną koncepcję diagnozy warunków społeczno-emocjonalnych, przestrzennych i materialnych rozwoju psychospołecznego dzieci w wieku poniemowlęcym. W opisie narzędzia zawarła wskaźniki dotyczące prawidłowego projektowania przestrzeni i dobierania przedmiotów potrzebnych do różnego rodzaju aktywności dzieci przebywających w placówkach wczesnej opieki i edukacji. Tak opracowane wskaźniki mogą stanowić podstawę do organizowania przestrzeni edukacyjnej dzieciom w wieku przedszkolnym. Poniższej przedstawiłam kilka przykładów, w jaki sposób te warunki mogą sprzyjać rozwojowi wyższych procesów poznawczych. Warto dodać, że próby określenia, które z umiejętności wchodzących w skład FW będą podlegały w konkretnym ćwiczeniu jest sztucznym zabiegiem³ ${ }^{3}$ gdyż przy każdej prostszej lub złożonej czynności potrzebne jest zaangażowanie wielu mniej lub bardziej złożonych umiejętności poznawczych, radzenia sobie z emocjami i kierowania zachowaniem składających się na dynamicznie rozwijający się system kontroli poznawczej, behawioralnej i emocjonalnej.

Ćwiczenie funkcji wykonawczych wiąże się z wykonywaniem zarówno w domu, jak i w przedszkolu codziennych czynności w określonej przestrzeni. Warunki przestrzenne dotyczą pomieszczenia na tyle przestronnego, żeby pozwalało na samodzielnie zorganizowanie zabawy w mniejszych grupach bądź na przebywanie samemu. Ważne byłoby zadbanie o wystrój wnętrza, czy to sali przedszkolnej, czy pokoju/miejsca dziecka w domu. Istotne jest tutaj dobranie pastelowych, delikatnych kolorów ścian, które sprzyjają wyciszeniu. Przekonanie o tym, że przestrzeń, w której przebywa dziecko, powinna być kolorowa i przepełniona stymulującymi bodźcami prowadzi do nadmiaru wrażeń i trudności w hamowaniu rozpraszających sygnałów płynących z zewnątrz, co utrudnia rozwój FW. Dodatkowo przestrzeń powinna mieć wydzielone części do konkretnych

3 Te trudności pojawiają się również w przygotowaniu zadań diagnostycznych, na podstawie których oceniany jest poziom FW. Okazuje się, że nie sposób zaplanować zadania, które nie wymagają udziału pamięci celu, ani wykonać ich w warunkach niewymagających udziału hamowania informacji nieistotnych (Nęcka, Orzechowski, Szymura 2013: 184). 
aktywności - jedzenia, snu/odpoczynku, zabawy, czynności higienicznych. Poszczególne części pomieszczenia można wydzielić spokojnymi kolorami, odpowiednimi fakturami dywanu lub też kolorem paneli, delikatnymi zasłonami, hamakami. Warto również uwzględnić zarówno w domu, jak i przedszkolu przestrzeń do bycia z samym sobą, aby dziecko mogło pobyć samo dyskretnie obserwowane przez dorosłego opiekuna gotowego do zaakceptowania potrzeby samotności, jak również przyjścia z pomocą wtedy, gdy dziecko jej potrzebuje. Dzięki takiej organizacji warunków przestrzennych dziecko może decydować o wyborze aktywności (w sytuacjach swobodnej zabawy), usytuowaniu jej w określonej przestrzeni oraz uczeniu się przestrzegania zasad związanych np. ze spożywaniem posiłku. Gdy dziecko poinformowane przez dorosłego dowiaduje się, że za chwilę będzie posiłek, rozpoczyna wykonywanie sekwencji czynności:

- odkłada zabawki do oznaczonego odpowiednim znaczkiem lub rysunkiem pudełka,

- odstawia pudełko na półkę,

- sprawdza, czy toaleta jest wolna, żeby umyć ręce,

- wchodzi do toalety,

- podwija rękawy,

- otwiera wodę,

- zwilża ręce,

- naciska dozownik mydła jedną ręką, jednocześnie podstawiając drugą, na którą opada mydło,

- mydli ręce, by powstała piana i rozprowadza ją po dłoniach,

- spłukuje wodą mydło z rąk,

- znajduje swój ręcznik lub wyciąga papierowy ręcznik z podajnika,

- wyciera ręce,

- odwiesza na miejsce ręcznik lub wyrzuca zużyty papier do kosza,

- opuszcza rękawy.

Cała sekwencja zachowań wymaga od dziecka koncentracji uwagi, kontroli poznawczej, aktualizowania w pamięci roboczej etapów mycia rąk i często uruchomienia procesu hamowania dystraktorów, bo dookoła inne dzieci wykonują podobne czynności i w tym czasie rozmawiają, śpiewają. Zdarza się, że pokonuje pokusę zbyt długiej zabawy wodą czy aktualizuje w pamięci informację o tym, że ręce 
po wyjściu z łazienki powinny być suche. Zatem ważne byłoby, żeby dziecko w przestrzeni, w której wykonuje te codzienne aktywności, miało dostęp do tych wszystkich przedmiotów potrzebnych do wykonania całej sekwencji czynności. Ograniczając dziecku w domu i w przedszkolu możliwość np. przygotowania stołu do posiłku (ustawienia talerza i kubka, ułożenia sztućców), samodzielnego nakładania sobie jedzenia z półmisków, nalewania wody oraz sprzątania po sobie ze stołu - ograniczamy nie tylko samodzielność dziecka, ale i możliwość ćwiczenia istotnych umiejętności poznawczych kontrolujących cały proces działania. Istotne jest również, żeby dziecko miało przestrzeń do przechowywania swoich osobistych rzeczy, do których nikt nie ma prawa bez zgody dziecka zaglądać. W domu może to być biurko/półka albo jedna wydzielona szuflada (w zależności od możliwości danej rodziny), w przedszkolu szuflada, pudełko, materiałowa kieszonka powieszona na krześle, na którym codziennie dziecko siada do posiłku. W ten sposób uczy się, że ma prawo decydować o przestrzeni, w której przebywa. Dodatkowo w przedszkolu warto zadbać o to, by dziecko miało zdjęcia najbliższej rodziny. Zaglądając bowiem do swoich rzeczy wtedy, gdy źle się czuje, uczy się samoregulacji pomocnej w radzeniu sobie $z$ trudnymi emocjami, np. tęsknotą za rodzicami, smutkiem z powodu kłótni. Ćwiczy pamięć korzystając ze swoich rzeczy, uczy się, żeby odkładać je na miejsce, bo w towarzystwie innych przedszkolnych zabawek może mieć trudności w odnalezieniu tych, które przyniosło z domu. Jeśli zdarzy się, że dziecko zgubi swoją zabawkę, korzystając ze śladów pamięci wraz z nauczycielem i rówieśnikami może odtworzyć to, co w ostatnim czasie robiło, żeby wiedzieć, gdzie powinno jej szukać - kolejna okazja do nauki hamowania narzucającej się reakcji (np. płaczu), po to, by osiągnąć cel, ćwiczenia pamięci i koncentracji uwagi. Przestrzeń do zaspokojenia ważnych potrzeb emocjonalnych dziecka sprzyja rozwijaniu zdolności przeżywania, nazywania i komunikowania emocji - ważnych umiejętności, które stanowią podstawę regulacji emocjonalnej silnie powiązanej z FW. Bez zaspokojenia tej emocjonalnej potrzeby dziecko na ogół nie ma siły i ochoty na poznawanie, przekształcanie otoczenia. Dodatkowo dziecko, które „wie, że pewne zdarzenia mogą wywołać pewne emocje, potrafi lepiej panować nad emocjami i hamować impulsy" 
(Dawson, Guare 2013: 113), które mogą utrudniać lub uniemożliwiać skuteczne działanie.

\section{Warunki materialne a wspomaganie funkcji wykonawczych}

Istotnym aspektem zarówno $\mathrm{w}$ środowisku rodzinnym, jak i przedszkolnym są warunki materialne stanowiące „wyposażenie przestrzeni funkcjonowania dziecka w przedmioty potrzebne do różnego rodzaju aktywności. Na warunki materialne składają się zatem:

- meble i akcesoria potrzebne do realizacji codziennych czynności i aktywności;

- zabawki przeznaczone do rozwoju poznawczego i motorycznego;

- materiały edukacyjne wspierające rozwój poznawczy i społeczno-emocjonalny” (Deptuła, Potorska, Borsich 2018: 81).

Dzieci w wieku przedszkolnym korzystając z dostępnych przedmiotów w domu i w przedszkolu powinny mieć możliwość czekania na swoją kolej związaną z umiejętnością hamowania reakcji. W powiązaniu $z$ warunkami materialnymi dzieje się to na przykład wtedy, gdy dziecko:

- czeka, aż inne dziecko skończy się bawić upragnioną zabawką, czeka na możliwość ułożenia puzzli, na zagranie w określoną grę, zbudowanie wielkiej budowli z rekordowo dużej liczby klocków;

- chce skorzystać z tych samych materiałów plastycznych, co inne dzieci;

- czeka na wręczaną przez nauczyciela kartkę do rysowania albo kolorowankę;

- czeka na swoją kolej, aby pokonać tor przeszkód.

Ważne, żeby dziecko miało czas na planowanie swojego działania, na przykład wykonując wydzierankę. Może wtedy zdecydować, czy najpierw podrzeć kolorowe papiery na kawałeczki, a potem przyklejać je do wzoru na kartce albo wydzierać kawałek po kawałku i od razu je przyklejać - takie działanie wymaga kontroli oraz uporządkowania i stanowi wyzwanie dla rozwijających się funkcji wykonawczych. Gdy dziecko ma możliwość podejmowania takich decyzji i wprowadza swój plan w życie, rozwija wyższe funkcje poznawcze, ćwicząc aktualizowanie potrzebnych danych w pamięci, hamowanie 
narzucających się reakcji, stara się elastycznie dostosowywać do zmiennych warunków (np. gdy brakuje jakiegoś odcienia kolorowego papieru), a gdy dorosły zadaje pytanie o wykonaną pracę, uczy się wchodzić na wyższy poziom myślenia o własnym działaniu i zastanawia się nad własną skutecznością (w wieku 5-6 lat).

Szczególne znaczenie w rozwoju funkcji wykonawczych mają różnego rodzaju gry planszowe i karciane. Większość gier i zabaw wymaga wykonania sekwencji działań według określonych zasad, co sprzyja rozwojowi funkcji wykonawczych. Najprostsze gry planszowe („Grzybobranie” czy „Wyścigi samochodowe”) albo gry karciane („Piotruś”) wymagają od dzieci utrzymywania uwagi - śledzenia tego, co zmienia się na planszy, gdy ruchy wykonują przeciwnicy, hamowania narzucających się reakcji, pobudzania do pracy pamięci roboczej, wytrwałości $\mathrm{w}$ dążeniu do celu, radzenia sobie z zakłóceniami nie tylko zewnętrznymi, ale i emocjami pojawiającymi się w trakcie gry. $\mathrm{Na}$ uwagę zasługują książeczki edukacyjne dla najmłodszych z serii mini PUS wraz z klockami, które można stosować już od drugiego roku życia. Dziecko ma za zadanie znaleźć w książeczce (z określoną historią bądź bohaterami albo zadaniami) zasadę, według której powinno ułożyć w klocki w pudełku. Dziecko ćwiczy umiejętność koncentracji uwagi, przerzutność uwagi oraz łączenie sekwencji działań (najpierw trzeba wziąć klocek z pudełka, potem sprawdzić, na którym z obrazków znajduje się ta sama liczba w tym samym kolorze, co na klocku, znaleźć w książeczce odpowiedź, sprawdzić liczbę na obrazku z odpowiedzią, odnaleźć ten numer w pudełku i na to miejsce odłożyć klocek, uwzględniając inny kolor liczby). Gdy skończy układanie klocków, zamyka pudełko, odwraca je otwiera i sprawdza, czy zadanie zostało prawidłowo wykonane, jeśli nie - zastanawia się, co poszło nie tak jak powinno i dlaczego nie pojawił się pożądany wzór. Kolejną okazją do rozwoju funkcji wykonawczych jest gra w „Zgadnij kto to?” (od piątego roku życia). Podczas tej gry dziecko poza umiejętnościami hamowania oraz przerzutnością uwagi uczy się przechowywać sporą porcję informacji w pamięci roboczej, podobnie jak w grach typu „memory”. Planowania strategii działania dziecko w wieku przedszkolnym może się nauczyć dzięki grze w „Dobble” (od czwartego roku życia). Oprócz ćwiczenia tych umiejętności podczas gier, warto żeby dorosły opiekun pomagał dziecku dostrzec, w jakich sytuacjach poza grą może zastosować zdobyte umiejętności. 


\section{Budowanie rusztowania}

Dobrze zorganizowana przestrzeń i dostępne materiały nie stanowią same w sobie wystarczających warunków do rozwoju dziecka. Jedynie osoba, która umie nimi refleksyjnie zarządzać, może sprawić, że wzorcowo zaprojektowana przestrzeń stanie się odpowiednim kontekstem rozwoju. Nauka umiejętności wykonawczych może się odbywać podczas naturalnych codziennych czynności, którym towarzyszy rozmowa. Trzyletnie dzieci, które doświadczyły w kontakcie z matką pomocy w postaci „słownego rusztowania” w wieku 6 lat przejawiają wyższe umiejętności rozwiązywania problemów i wytrwałego dążenia do celu niż dzieci matek, które nie stosują tej techniki (Dawson, Guare 2012: 110).

Główny opiekun ma możliwość udzielania dziecku wyjaśnień, wskazówek, zadawania pytań dostosowanych do jego poziomu rozwojowego, które pomogą mu wykonać zadanie. W ten sposób dziecko uczy się dostrzegać i rozumieć relacje, łączyć ze sobą nową wiedzę z wcześniej nabytą. Wszystkie te umiejętności wiążą się z metapoznaniem, czyli zdolnością zdystansowania się do własnego działania i pozwalają na monitorowanie podjętych działań (Dawson, Guare 2012: 10). Dzięki budowaniu rusztowania, po którym dziecko wspina się $\mathrm{z}$ asekuracją i pomocą dorosłego, zwiększa się szansa na wykonanie zadania, które pojawia się w jego sferze najbliższego rozwoju.

W poniższej tabelce przedstawiłam przykłady rusztowań słownych zastosowanych w kontakcie $z$ dzieckiem w wieku przedszkolnym.

Tabela 1. Przykłady rusztowań przeznaczonych dla dziecka w wieku przedszkolnym wspomagających rozwój funkcji wykonawczych

\begin{tabular}{|c|c|}
\hline Kategoria rusztowania & Przykład komunikatu \\
\hline $\begin{array}{l}\text { Pytania/stwierdzenia łączqce przedmioty z miej- } \\
\text { scem }\end{array}$ & $\begin{array}{l}\text { „Który spodeczek pasuje do tej filiżanki?" } \\
\text { "Czego brakuje na stoliku, jeśli chcemy zjeść pod- } \\
\text { wieczorek?" }\end{array}$ \\
\hline $\begin{array}{l}\text { Powiqzanie obecnego działania, przedmiotu lub } \\
\text { tematu rozmowy z poprzednim doświadczeniem }\end{array}$ & $\begin{array}{l}\text { "To jest pociag, jeździ, po szynach jak tramwai, } \\
\text { którym jeździmy do babci" } \\
\text { "Ta zabawa przypomina nasza zabawę w berka, } \\
\text { bo też trzeba uciekać, gdy ktoś cię goni" }\end{array}$ \\
\hline $\begin{array}{l}\text { Używanie słów do opisu przeżyć, zwłaszcza w od- } \\
\text { niesieniu do doznań zmysłowych }\end{array}$ & $\begin{array}{l}\text { „Na tym zdięciu dziewczynka ma bardzo zmar- } \\
\text { szczony nos i zmrużone oczy, gdy bierze do ust } \\
\text { plasterek cytryny" } \\
\text { "Ta pani śpiewa bardzo wysokim głosem" }\end{array}$ \\
\hline
\end{tabular}




\begin{tabular}{|c|c|}
\hline Kategoria rusztowania & Przykład komunikatu \\
\hline $\begin{array}{l}\text { Opis właściwości przedmiotu wskazujacych na } \\
\text { jego wyiqtkowość/funkcję/specyficzne cechy, które } \\
\text { mogq być przydatne do rozwiqzania problemu }\end{array}$ & $\begin{array}{l}\text { „Ten kolor kulki różni się od koloru kulek, które już } \\
\text { włożyłaś do koszyka” } \\
\text { „Potrzebny nam jest przejrzysty okragły klocek, } \\
\text { nadaje się na koło do samochodu” }\end{array}$ \\
\hline $\begin{array}{l}\text { Określenie funkcii lub działania, które można wy- } \\
\text { konać za pomoca określonego przedmiotu }\end{array}$ & $\begin{array}{l}\text { „Łyżkq też można wykopać dołek w piasku" } \\
\text { „To sq nożyczki, które wycinają wzorek na brzegu } \\
\text { kartki" }\end{array}$ \\
\hline Słowny opis demonstracii działania & $\begin{array}{l}\text { „Wyrzucamy wszystkie kawałki puzzli i odwraca- } \\
\text { my, żeby było widać kolorowa czéść" } \\
\text { „W ten sposób zapinam guziki w kamizelce misia” }\end{array}$ \\
\hline Powiqzanie stanów emocjonalnych z przyczynq & $\begin{array}{l}\text { „Siostrzyczka ucieszyła się, gdy podzieliłeś się } \\
\text { foremkami” } \\
\text { „Babci będzie przykro, jeśli wejdziesz na dywan } \\
\text { w zabłoconych butach" }\end{array}$ \\
\hline Podkreślenie zwiqzzu między przyczynq a skutkiem & $\begin{array}{l}\text { „Jeśli będziesz rzucał książkq, rozerwie się okład- } \\
\text { ka” } \\
\text { „Bez założenia czapki na głowę nie pójdziemy na } \\
\text { sanki, ponieważ od zimna możesz się przeziębić” }\end{array}$ \\
\hline Łq̨czenie przedmiotów w ogólne kategorie & $\begin{array}{l}\text { "Tu jest jabłko, tam gruszka i kupimy jeszcze bana- } \\
\text { ny, będziemy mieli w koszyku dużo owoców" } \\
\text { "W twoim warsztacie jest młotek, śrubokręt i piła - } \\
\text { to jest warsztat dobrze wyposażony w narzędzia" }\end{array}$ \\
\hline $\begin{array}{l}\text { Pomoc w rozumieniu działania poprzez połączenie } \\
\text { dwóch aspektów działania }\end{array}$ & $\begin{array}{l}\text { „Zróbmy ciastka, potrzebna nam będzie mąka, } \\
\text { masło i jajka” } \\
\text { „Pobawmy się w chowanego, potrzebujemy kogoś, } \\
\text { kto będzie czekał aż się schowamy i będzie nas } \\
\text { szukał” }\end{array}$ \\
\hline
\end{tabular}

Źródło: Opracowanie własne na podstawie Dawson, Guare (2013).

Budowanie rusztowania wymaga od rodziców i nauczycieli życzliwego zainteresowania aktywnością dziecka i może być jednym ze sposobów niwelowania zaburzeń pojawiających się w realizacji ról rodzicielskich - czynnika ryzyka sięgania po substancje uzależniające i ryzykowne zachowania. Nawet jeśli rodzice nie potrafią zapewnić dziecku odpowiednich warunków do rozwoju, nauczyciel edukacji przedszkolnej może mu pomóc w rozwijaniu FW. W takiej sytuacji przedszkole staje się miejscem wyrównywania szans edukacyjnych dzieci i daje im nadzieję na doświadczenie sukcesu w dalszej edukacji pomimo braku wsparcia ze strony rodziców. 


\section{Podsumowanie}

Wiedza na temat stanu funkcji wykonawczych intensywnie rozwijających się u dzieci w wieku przedszkolnym może prowadzić do planowania wczesnych działań profilaktycznych, które dają szansę nie tylko na poprawienie aktualnego dobrostanu dzieci, ale także ich lepszego radzenia sobie w niedalekiej przyszłości chociażby z wymaganiami szkoły i poczuciem przynależności do grupy rówieśniczej istotnymi czynnikami chroniącymi przed używaniem alkoholu. Odpowiednia organizacja warunków przestrzennych i materialnych stanowi o możliwościach środowiska domowego i placówki przedszkolnej, najważniejsze jednak są wczesne działania profilaktyczne, które zostają podjęte przez refleksyjnych, empatycznych i ciepłych w kontakcie z dzieckiem rodziców i nauczycieli.

\section{Bibliografia}

Bańko A. (2002). Spoteczna psychologia środowiskowa, Warszawa: Wydawnictwo Naukowe Scholar.

Blair C., Zelazo P.D., Greenberg M.T. (2005). The Measurement of Executive Function in Early Childhood, „Developmental Neuropsychology”, t. 28, nr 2, s. 561-571. DOI: 10.1207/s15326942dn2802_1.

Bull R., Espy K.A., Wiebe S.A. (2008). Short-Term Memory, Working Memory, and Executive Functioning in Preschoolers: Longitudinal Predictors of Mathematical Achievement at Age 7 Years, ,Journal Developmental Neuropsychology",t. 33, nr 3, s. 205-228. DOI: 10.1080/87565640801982312.

Brzezińska A.I., Nowotnik A. (2012). Funkcje wykonawcze a funkcjonowanie dziecka w środowisku przedszkolnym i szkolnym, „Edukacja. Studia, Badania, Innowacje", nr 1(117), s. 61-74.

Brzezińska A.I., Appelt K., Ziółkowska B. (2016). Psychologia rozwoju człowieka, Sopot: Gdańskie Wydawnictwo Psychologiczne.

Cierpiałowska L., Ziarko M. (2010). Psychologia uzależnieńn-Alkoholizm, Warszawa: Wydawnictwa Akademickie i Profesjonalne.

Dawson P., Guare R. (2012). Zdolne, ale rozkojarzone. Wspieranie rozwoju $d z i e c k a$ za pomoca umiejętności wykonawczych, przeł. W. Turopolski, Kraków: Wydawnictwo UJ.

Deptuła M. (2005). Indywidualne ścieżki ryzyka i zwiqzana z nimi interwencja profilaktyczna, [w:] M. Deptuła (red.), Diagnostyka, profilaktyka, socjoterapia w teorii i praktyce pedagogicznej, Bydgoszcz: Wydawnictwo UKW, s. 158-184. 
Deptuła M., Potorska A., Borsich S. (2018). Wczesna profilaktyka problemów w rozwoju psychospotecznym i ryzykownych zachowań dzieci i mtodzieży, Warszawa: Wydawnictwo Naukowe PWN.

Erikson E.H. (1997). Dzieciństwo i spoteczeństwo, przeł. P. Hejmej, Poznań: Dom Wydawniczy Rebis.

Hammond S.I., Müller U., Carpendale J.I.M., Bibok M.B., Liebermann-Finestone D.P. (2012). The Effects of Parental Scaffolding on Preschoolers' Executive Function, „Developmental Psychology”, t. 48, nr 1, s. 271-281, http://dx.doi.org/10.1037/a0025519.

Holmes Ch.J., Kim-Spoon J., Deater-Deckard K., Tech V. (2016). Linking Executive Function and Peer Problems from Early Childhood through Middle Adolescence, „Journal of Abnormal Child Psychology”, t. 44, nr 1, s. 33-42. DOI: $10.1007 / \mathrm{s} 10802-015-0044-5$.

Kielar-Turska M., Białecka-Pikul M., Skórska A. (2006). Rozwój zdolnosci mentalizacji. $Z$ badan nad zwiqzkiem teorii umystu, sprawności językowych i funkcji zarzadzajacych, „Psychologia Rozwojowa” t. 11, nr 2, s. 35-47, <http://cejsh.icm.edu.p1/cejsh/element/bwmeta1.element.ojs-issn-2084-3879-year-2006-volume-11-issue-2-article-3033> [dostęp: 20.07.2019].

Myiake A., Friednam N.P. (2000). The Nature and Organization of Individual Differences in Executive Functions: Forum General Conclusions, „Current Directions in Psychological Science”, t. 21, nr 1, s. 8-14. DOI: 10.1177/0963721411429458.

Nęcka E., Orzechowski J., Szymura B. (2013). Psychologia poznawcza, Warszawa: Wydawnictwo Naukowe PWN.

Packwood S., Hodgetts H.M., Tremblay S. (2011). A Multiperspective Approach to the Conceptualization of Executive Functions, "Journal of Clinical and Experimental Neuropsychology", t. 33, nr 4, s. 456-470. DOI: 10.1080/13803395.2010.533157.

Putko A. (2008). Dziecięca "teoria umystu" w fazie jawnej i utajonej a funkcje wykonawcze, Poznań: Wydawnictwo Naukowe UAM.

Sikorska I. (2016). Odporność psychiczna w okresie dzieciństwa, Kraków: Wydawnictwo Uniwersytetu Jagiellońskiego.

Smykowski B. (2005). Wiek przedszkolny. Jak rozpoznać potencjat dziecka?, [w:] A.I. Brzezińska (red.), Portrety psychologiczne cztowieka, Sopot: Gdańskie Wydawnictwo Psychologiczne, s. 165-205.

Valcan D.S., Davis H., Pino-Psternak D. (2018). Parental Behaviours Predicting Early Childhood Executive Functions: A Meta-Analysis, „Education Psychology Review”, t. 30, nr 4, s. 607-649. DOI: 10.1007/ s10648-017-9411-9.

Whitebread D. (2018). Quality in Early Childhood Education: The Contribution of Developmental Psychology, [w:] M. Fleer, B. van Oers (red.), International Handbook of Early Childhood Education, t. 1, Dordrecht: Springer, s. 319-334. DOI: 10.1007/978-94-024-0927-7_14. 
Wygotski L.S. (1971). Wybrane prace psychologiczne, przeł. E. Flesznerowa, J. Fleszner, Warszawa: Państwowe Wydawnictwo Naukowe.

\author{
ADRES DO KORESPONDENCJI \\ Dr Blanka Poćwiardowska \\ Uniwersytet Kazimierza Wielkiego w Bydgoszczy \\ Wydział Pedagogiki \\ e-mail: blankap@ukw.edu.pl
}

